\title{
Meyerson Nevus Mimicking Malignant Melanoma
}

\section{Meyerson Nevus Imitando Melanoma Maligno}

Filipa Tavares Almeida ${ }^{1}$, Regina Caldas ${ }^{1}$, Teresa Pereiro ${ }^{1}$, Celeste Brito ${ }^{1}$

Meyerson nevus represents an uncommon clinical and histological variation of melanocytic lesions that is characterized by an eczematous halo surrounding a melanocytic nevus. ${ }^{1}$ It was first reported by Meyerson and it typically clears spontaneously or resolves with topical corticotherapy. $^{2}$

We report the case of an atypical Meyerson nevus in which, despite intense pruritus, both an eczematous eruption and dermoscopic patterns imputable to a melanocytic lesion were lacking.

A 29-year-old man, annually evaluated by dermoscopy in our department, presented with a new pigmented lesion located on the lower right back. The patient reported severe local itch over the past few weeks. Patient medical history was unremarkable, regarding eczema or other cutaneous diseases. Physical examination revealed a homogeneous oval brown papule, with 6 × 3 mm (Fig. 1).
Dermoscopy examination of the lesion revealed an unspecific pattern characterized by a diffuse brown structureless area and multifocal hypopigmented and scarlike spots with a few sparse brown dots (Fig. 2).

Due to the absence of a distinct pattern and based on the two-step procedure for dermoscopic evaluation, we decided to proceed to surgical excision of the lesion. Histopathological examination showed an intradermal melanocytic nevus associated with subacute eczema.

The pathogenesis of Meyerson phenomenon is unknown. It is usually seen in otherwise healthy young male adults and it clinically presents as a pruriginous eczematous halo encircling a pigmented lesion. ${ }^{2}$ Besides its reports associated with melanocytic lesions, it can also appear around non-melanocytic lesions, such as molluscum contagiosum, seborrheic keratosis, dermatofibromas and basal cell and squamous cell carcinomas. Concerning treatment, topical corticotherapy 


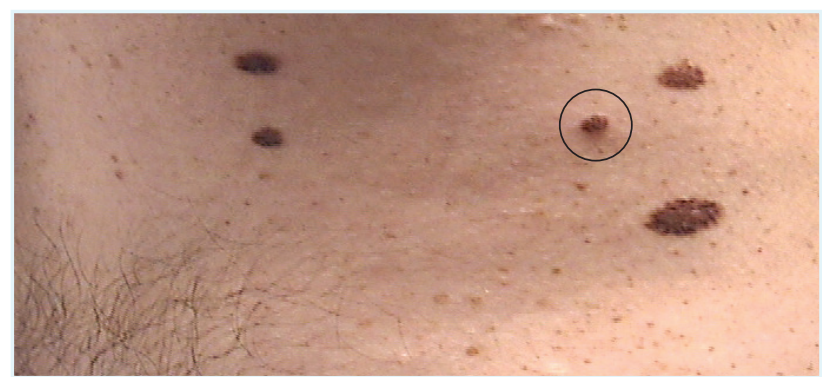

FIGURE 1. Oval brown papule located on the lower right back (inside the black circle).

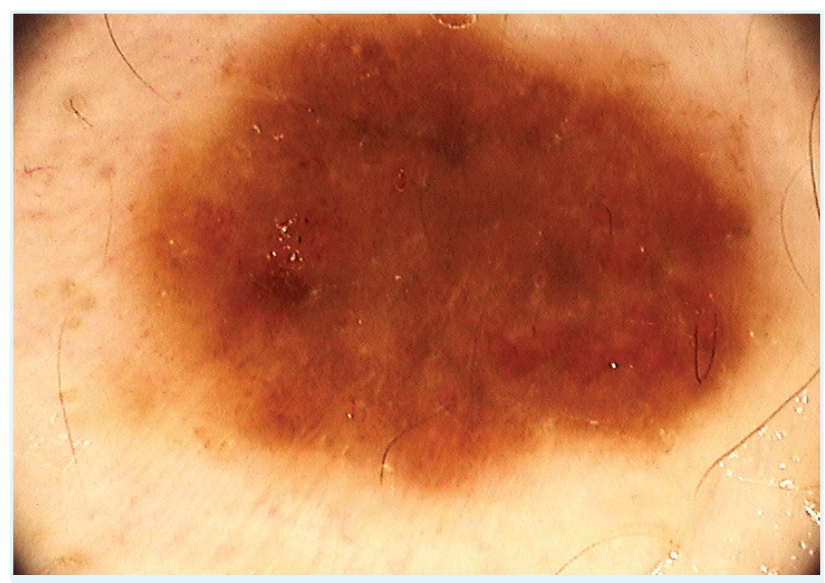

FIGURE 2. Diffuse brown background with multifocal scar-like hypopigmented areas and sparse pigmented dots (dermoscopic image, $\times 30$ magnification).

in association with regular dermoscopic follow-up can be performed. Surgical excision should be considered in lesions refractory to treatment and when suspicious lesions are present. ${ }^{1}$

Although Meyerson phenomenon is rarely reported in the literature, it is important to be aware of this diagnosis and to consider it in the differential diagnosis of pruritic melanocytic lesions. Furthermore, diagnostic challenges occur when typical characteristics are not present and lesions can mimic malignant tumors, such as melanoma. Our case reports an interesting and unusual presentation of Meyerson nevus, highlighting the importance of histological examination to warrant a prompt and correct diagnosis.

CONFLICTS OF INTEREST: The authors declare that they have no conflicts of interest.

FINANCIAL SUPPORT: This work has not received any contribution, grant or scholarship.

CONFIDENTIALITY OF DATA: The authors declare that they have followed the protocols of their work center on the publication of data from patients.

PROTECTION OF HUMAN AND ANIMAL SUBJECTS: The authors declare that the procedures followed were in accordance with the regulations of the relevant clinical research ethics committee and with those of the Code of Ethics of the World Medical Association (Declaration of Helsinki).

CONFLITOS DE INTERESSE: OS autores declaram não ter qualquer conflito de interesse na realização do presente trabalho.

FONTES DE FINANCIAMENTO: Não houve qualquer fonte de financiamento na realização do presente trabalho.

CONFIDENCIALIDADE DOS DADOS: Os autores declaram ter seguido os protocolos da sua instituição acerca da publicação dos dados de doentes.

PROTEÇÃO DE PESSOAS E ANIMAIS: Os autores declaram que os procedimentos seguidos na elaboração do presente trabalho estão em conformidade com as normas das comissões de investigação clínica e de ética, bem como da declaração de Helsínquia e da Associação Médica Mundial.

\section{REFERENCES}

1. Balato A, Lembo S, Cirillo T, Megna M, Napolitano M, Balat N. Meyerson phenomenon around naevi: resolution after sun exposure? Acta Dermato-Venereol. 2011;91:352-3. doi: 10.2340/00015555-1059.

2. Gabbi TV, Omar ED, Criado PR, Valente NY, Martins JE. Clinical, dermoscopic and histopathological evaluation of the Meyerson nevus: case report. An Bras Dermatol. 2010;85:681-3. 